CARNEIRO, Cheila da Silva dos Passos. RODRIGUES, Patrícia Silva. PASOLD, Cesar Luiz. A transnacionalização da sustentabilidade no direito ambiental. Revista Eletrônica Direito e Política, Programa de Pós-Graduação Stricto Sensu em Ciência Jurídica da UNIVALI, Itajaí, v.11, n.2, 2o quadrimestre de 2016. Disponível em: www.univali.br/direitoepolitica - ISSN 1980-7791.

\title{
A TRANSNACIONALIZAÇÃO DA SUSTENTABILIDADE NO DIREITO AMBIENTAL
}

\author{
LE DÉVELOPPEMENT DURABLE TRANSNATIONALISATION EN DROIT DE \\ L'ENVIRONNEMENT
}

\section{Cheila da Silva dos Passos Carneiro ${ }^{1}$ \\ Patrícia Silva Rodrigues ${ }^{2}$ \\ Cesar Luiz Pasold ${ }^{3}$}

${ }^{1}$ Doutoranda em Ciência Jurídica pela Universidade do Vale do Itajaí - UNIVALI. Mestra em Ciência Jurídica pela Universidade do Vale do Itajaí - UNIVALI com dupla titulação em Derecho Ambiental y de la Sostenibilidad pela Universidade de Alicante na Espanha. Docente no Centro Universitário para o Desenvolvimento do Alto Vale do Itajaí UNIDAVI. Membro do Grupo de Pesquisa Direito Ambiental, Transnacionalidade e Sustentabilidade, da Universidade do Vale do Itajaí - UNIVALI. Líder do Grupo de Pesquisa Meio Ambiente do Trabalho e Seguridade Social, do Centro Universitário para o Desenvolvimento do Alto Vale do Itajaí - UNIDAVI. Coordenadora na UNIDAVI do projeto FAPESC intitulado AMBIENTALIZAÇÃO E SUSTENTABILIDADE NA EDUCAÇÃO SUPERIOR: subsídios às Políticas Institucionais em Santa Catarina. Email: cheila@unidavi.edu.br

2 Doutoranda em Ciências Jurídicas junto à Universidade do Vale do Itajaí (UNIVALI). Mestre em Ciência Jurídica pela Universidade do Vale do Itajaí - UNIVALI com dupla titulação em Derecho Ambiental y de la Sostenibilidad pela Universidade de Alicante na Espanha. Servidora pública do Tribunal de Justiça de Santa Catarina (TJSC) Professora junto à Universidade Sociedade Educacional de Santa Catarina (UNISOCIESC), Joinville - SC, e-mail para contato: patriciasrodrigues@tjsc.jus.br.

3 Doutor em Direito do Estado pela Faculdade de Direito do Largo São Francisco - -USP; Pós Doutor em Direito das Relações Sociais pela UFPR ; Mestre em Instituições Jurídico-Políticas pela UFSC. É Consultor de Organizações nas Áreas Jurídica e Axiológica. Advogado-OAB/SC 943. Docente da UNIVALI, lecionando as disciplinas: (1) Teoria do Estado e da Constituição e (2) Seminário de Metodologia da Pesquisa Jurídica, ambas no Curso de Doutorado em Ciência Jurídica. Autor, entre outras, das Obras: Metodologia da Pesquisa Jurídica: Teoria e Prática (13 ed.rev.atual.amp. Florianópolis: Conceito Editorial, 2015); Função Social do Estado Contemporâneo (4 ed. Itajai: Univali-2013- ebook, disponível gratuitamente : http://siaiapp28.univali.br/LstFree.aspx ; Ensaio sobre a Ética de Norberto Bobbio (Florianópolis: Conceito Editorial,2008); Coautor e Coorganizador entre outros, de: Reflexões sobre Teoria da Constituição e do Estado (Florianópolis: Insular,2013) ;Ensaios sobre Meio Ambiente e Direito Ambiental (Florianópolis: Insular, 2012) ; Primeiros Ensaios de Teoria do Estado e da Constituição (Curitiba: Juruá,2010). 
CARNeIRO, Cheila da Silva dos Passos. RODRIGUES, Patrícia Silva. PASOLD, Cesar Luiz. A transnacionalização da sustentabilidade no direito ambiental. Revista Eletrônica Direito e Política, Programa de Pós-Graduação Stricto Sensu em Ciência Jurídica da UNIVALI, Itajaí, v.11, n.2, 2o quadrimestre de 2016. Disponível em: www.univali.br/direitoepolitica - ISSN 1980-7791.

SUMÁRIO: Introdução; 1. Da sustentabilidade; 2. Da transnacionalidade do direito ambiental; 3. A quebra de fronteiras da sustentabilidade: a transnacionalidade; 4. Judicialização da sustentabilidade e transnacionalização; 4.1 constitucionalização da sustentabilidade; 4.2 a transnacionalização sustentável; 4.3 responsabilidade da transnacionalização e implantação da sustentabilidade; Considerações Finais; Referências das Fontes Citadas

\section{RESUMO}

O objetivo deste artigo é estudar acerca da transnacionalização da Sustentabilidade do Direito Ambiental. Sustentabilidade e transnacionalização não são apenas palavras da moda, seus significados ultrapassam fronteiras e ganham dimensões globais, investigam-se questões como saber se é possível a Sociedade identificar os riscos e os reflexos ambientais decorrentes da globalização, para tanto, à metodologia empregada, registra-se que, na Fase de Investigação, o Método ${ }^{4}$ utilizado foi o Indutivo, na fase de Tratamento dos Dados o Cartesiano e o Método Analítico, este último na perspectiva de Norberto Bobbio $^{5}$, no Relatório da Pesquisa, foi empregada a Base Indutiva ${ }^{6}$. As considerações finais trazem em seu bojo comentários acerca da comprovação da hipótese básica da possibilidade da Transnacionalização da Sustentabilidade no Direito Ambiental.

PALAVRAS-CHAVE: Transnacionalização; Sustentabilidade; Direito Ambiental.

\section{Résumé}

Presidente da Academia Catarinense de Letras Jurídicas-ACALEJ (em mandato de 20132017). >CV Lattes: http://lattes.cnpq.br/6851573982650146 > Site : www.cesarluizpasold.com.br > E-mail: clp@cesarluizpasold.com.br.

4 "Método é forma lógico-comportamental na qual se baseia o Pesquisador para investigar, tratar os dados colhidos e relatar os resultados". PASOLD, Cesar Luiz. Metodologia da Pesquisa Jurídica, cit.p.206.

5 Vide PASOLD, Cesar Luiz. Ensaio sobre a Ética de Norberto Bobbio. Florianópolis: Conceito Editorial, 2008.p. 193.

6 Sobre os métodos e técnicas nas diversas fases da Pesquisa Científica, vide PASOLD, Cesar Luiz. Metodologia da Pesquisa Jurídica: Teoria e Prática. 13. ed. rev. atual .amp. Florianópolis: Conceito Editorial, 2015. P. 81 a 111. 
CARNeIRO, Cheila da Silva dos Passos. RODRIGUES, Patrícia Silva. PASOLD, Cesar Luiz. A transnacionalização da sustentabilidade no direito ambiental. Revista Eletrônica Direito e Política, Programa de Pós-Graduação Stricto Sensu em Ciência Jurídica da UNIVALI, Itajaí, v.11, n.2, 2o quadrimestre de 2016. Disponível em: www.univali.br/direitoepolitica - ISSN 1980-7791.

Le but de cet article est d'étudier sur le Transnationalisation Sustainability Environmental Law. La durabilité et la transnationalisation sont pas seulement des mots buzz, leurs significations au-delà des frontières et à acquérir une dimension mondiale, d'enquêter sur des questions telles que si elle est possible, la Société d'identifier les risques et les conséquences environnementales de la mondialisation, par conséquent, la méthodologie employée, Enrol que, dans la phase de recherche, la méthode utilisée était le inductive dans les données de la méthode cartésienne et analytique phase de traitement, ce dernier en vue de Norberto Bobbio, le rapport de recherche, il a utilisé la base inductive. Les considérations finales portent les commentaires des bagages sur la preuve de l'hypothèse de base de la possibilité de transnationalisation durabilité en droit de l'environnement.

Mots-clés: Transnationalisation; Durabilité; Droit de l'environnement.

\section{INTRODUÇÃO}

O objeto do presente artigo científico é a Transnacionalização da Sustentabilidade no Direito Ambiental.

O objetivo geral deste artigo científico é investigar a possibilidade da Transnacionalização da Sustentabilidade no Direito Ambiental.

Na delimitação do tema levantou-se o seguinte problema: É possível a Transnacionalização da Sustentabilidade no Direito Ambiental?

Para o equacionamento do problema levantou-se a seguinte hipótese: supõe-se que é possível a Transnacionalização da Sustentabilidade no Direito Ambiental. 
CARNeIRO, Cheila da Silva dos Passos. RODRIGUES, Patrícia Silva. PASOLD, Cesar Luiz. A transnacionalização da sustentabilidade no direito ambiental. Revista Eletrônica Direito e Política, Programa de Pós-Graduação Stricto Sensu em Ciência Jurídica da UNIVALI, Itajaí, v.11, n.2, 2o quadrimestre de 2016. Disponível em: www.univali.br/direitoepolitica - ISSN 1980-7791.

Quanto à metodologia empregada, registra-se que, na Fase de Investigação, o Método ${ }^{7}$ utilizado foi o Indutivo, na fase de Tratamento dos Dados o Cartesiano e o Método Analítico, este último na perspectiva de Norberto Bobbio ${ }^{8}$, no Relatório da Pesquisa, foi empregada a Base Indutiva $^{9}$. Foram acionadas as técnicas do referente ${ }^{10}$, da categoria ${ }^{11}$, dos conceitos operacionais $^{12}$, da pesquisa bibliográfica ${ }^{13}$ e do fichamento ${ }^{14}$.

A Sustentabilidade, enquanto objetivo vital para a perpetuação da raça humana, e termo vastamente utilizado, visa ao emprego de técnicas de preservação e perpetuação da condição humana.

7 "Método é forma lógico-comportamental na qual se baseia o Pesquisador para investigar, tratar os dados colhidos e relatar os resultados". PASOLD, Cesar Luiz. Metodologia da Pesquisa Jurídica, cit.p.206.

8 Vide PASOLD, Cesar Luiz. Ensaio sobre a Ética de Norberto Bobbio. Florianópolis: Conceito Editorial, 2008.p. 193.

9 Sobre os métodos e técnicas nas diversas fases da Pesquisa Científica, vide PASOLD, Cesar Luiz. Metodologia da Pesquisa Jurídica: Teoria e Prática. 13. ed. rev. atual .amp. Florianópolis: Conceito Editorial, 2015. P. 81 a 111.

10 "explicitação prévia do motivo, objetivo e produto desejado, delimitado o alcance temático e de abordagem para uma atividade intelectual, especialmente para uma pesquisa". PASOLD, Cesar Luiz. Metodologia da Pesquisa Jurídica: Teoria e Prática. 13. ed. ver. atual. amp. Florianópolis: Conceito Editorial, 2015. p. 58.

11 "palavra ou expressão estratégica à elaboração e/ou expressão de uma ideia". PASOLD, Cesar Luiz. Metodologia da Pesquisa Jurídica: Teoria e Prática. 13. ed. rev. atual.amp. Florianópolis: Conceito Editorial, 2015. p. 27.

12 "definição estabelecida ou proposta para uma palavra ou expressão, com o propósito de que tal definição seja aceita para os efeitos das ideias expostas". PASOLD, Cesar Luiz. Metodologia da Pesquisa Jurídica: Teoria e Prática. 13. ed. rev. atual.amp. Florianópolis: Conceito Editorial, 2015. p. 39.

13 "Técnica de investigação em livros, repertórios jurisprudenciais e coletâneas legais". PASOLD, Cesar Luiz. Metodologia da Pesquisa Jurídica: Teoria e Prática. 13. ed. rev. atual.amp. Florianópolis: Conceito Editorial, 2015. p. 215.

14 "Técnica que tem como principal utilidade otimizar a leitura na Pesquisa Científica, mediante a reunião de elementos selecionados pelo Pesquisador que registra e/ou resume e/ou reflete e/ou analisa de maneira sucinta, uma Obra, um Ensaio, uma Tese ou Dissertação, um Artigo ou uma aula, segundo Referente previamente estabelecido". PASOLD, Cesar Luiz. Metodologia da Pesquisa Jurídica: Teoria e Prática. 13. ed. rev. atual.amp. Florianópolis: Conceito Editorial, 2015. p. 114 e 115. 
CARNEIRO, Cheila da Silva dos Passos. RODRIGUES, Patrícia Silva. PASOLD, Cesar Luiz. A transnacionalização da sustentabilidade no direito ambiental. Revista Eletrônica Direito e Política, Programa de Pós-Graduação Stricto Sensu em Ciência Jurídica da UNIVALI, Itajaí, v.11, n.2, 2o quadrimestre de 2016. Disponível em: www.univali.br/direitoepolitica - ISSN 1980-7791.

Com os grandes avanços do século XXI, no qual se caminha para uma única Sociedade mundial, levanta-se a questão se é possível a Sociedade identificar os riscos e os reflexos ambientais decorrentes da globalização?

Com o cenário mundial atual seria possível ofertar uma solução para os problemas do Desenvolvimento Sustentável? Quais seriam os objetivos a serem alcançados? E a que preço? Qual o custo e quanto tempo que seria dispendido para alcançar os objetivos?

Não é possível a preservação egocêntrica somente do que está a nossa volta, o Meio Ambiente é de todos e para todos, e é com essa visão que se busca mecanismos para ir mais além ao emprego de técnicas sustentáveis.

O ambiente chegou a um ponto degradante, cobrando da comunidade a tomada de decisões e o emprego de princípios como o da prevenção e precaução, que devem ser empregados em esfera global.

A Transnacionalização nasce com a Globalização, e é o mecanismo que vem com 0 intuito de propagar e romper barreiras para a sustentabilidade. De maneira singela, afirma-se que ela quebra barreiras, fazendo com que a aplicação de um sistema sustentável atinja proporções globais.

Enquanto fenômeno, a Transnacionalização, tal como a Globalização, também permite a aproximação dos entes da comunidade de maneira ativa, tanto na preservação propriamente dita, como a produção de leis e tomada de decisões, para a construção de um Estado Democrático voltado a questões ambientais. 
CARNeIRO, Cheila da Silva dos Passos. RODRIGUES, Patrícia Silva. PASOLD, Cesar Luiz. A transnacionalização da sustentabilidade no direito ambiental. Revista Eletrônica Direito e Política, Programa de Pós-Graduação Stricto Sensu em Ciência Jurídica da UNIVALI, Itajaí, v.11, n.2, 2o quadrimestre de 2016. Disponível em: www.univali.br/direitoepolitica - ISSN 1980-7791.

A preservação do ambiente em nível nacional não garante a resolução dos problemas, sendo necessário levar as normas à esfera global. O Estado não pode garantir a saúde do planeta agindo somente em sua própria jurisdição.

A criação de normas internas, como políticas de Educação Ambiental, tratados e convenções, assim como a inclusão em textos constitucionais, é o alicerce para a aplicação e punição do não cumprimento de normas de cunho ambiental e políticas de desenvolvimento sustentável.

Desse modo, o presente artigo pretende fomentar o desenvolvimento de uma consciência para a necessidade de uma Transnacionalização da Sustentabilidade do Direito Ambiental, bem como tratar sobre seu conceito e suas atribuições como instrumento de Política Ambiental.

Salienta-se que a palavra Sociedade ${ }^{15}$, quando não estiver em transcrições literais, será grafada com o S em letra maiúscula.

\section{DA SUSTENTABILIDADE}

A Sustentabilidade é um objetivo em comum de toda a humanidade, pois a utilização dos recursos naturais, de maneira desenfreada, forçou o ser humano a rever seus conceitos e estilo de vida.

15 A opção dos autores do presente artigo para este tipo de grafia se sustenta no seguinte argumento: "[...] se a Categoria ESTADO merece ser grafada com a letra E maiúscula, muito mais merece a Categoria SOCIEDADE ser grafada com a letra $\mathrm{S}$ em maiúscula, porque, afinal, a SOCIEDADE é a criadora e mantenedora do Estado! Por coerência, pois, se a criatura/mantida (Estado) vem grafada com E maiúsculo, também e principalmente a criadora/mantenedora (Sociedade) deve ser grafada com o $\mathrm{S}$ maiúsculo!". Conforme PASOLD, Cesar Luiz. Metodologia da Pesquisa Jurídica: Teoria e Prática. 13 ed. rev. Florianópolis: Conceito Editorial, 2015. p. 175. (negritos e destaques no original) 
CARNeIRO, Cheila da Silva dos Passos. RODRIGUES, Patrícia Silva. PASOLD, Cesar Luiz. A transnacionalização da sustentabilidade no direito ambiental. Revista Eletrônica Direito e Política, Programa de Pós-Graduação Stricto Sensu em Ciência Jurídica da UNIVALI, Itajaí, v.11, n.2, 2o quadrimestre de 2016. Disponível em: www.univali.br/direitoepolitica - ISSN 1980-7791.

O termo "sustentabilidade", amplamente utilizado na atualidade, advém da palavra latina sustentare, que significa sustentar ${ }^{16}$. Boff traz como conceito de Sustentabilidade:

O conjunto dos processos e ações que se destinam a manter a vitalidade e a integridade da Mãe Terra, a preservação de seus ecossistemas com todos os elementos físicos, químicos e ecológicos que possibilitam a existência e a reprodução da vida, 0 atendimento das necessidades da presente e das futuras gerações, e a continuidade, a expansão e a realização das potencialidades da civilização humana em suas várias expressões. ${ }^{17}$

Para Bosselmann "o termo sustentabilidade revela sua mensagem para a atualidade: se você quer prosperidade econômica a longo prazo, cuide primeiro do meio ambiente!"18

Ainda, sobre a utilização dos recursos naturais e o termo em comento o autor Aquino discorre que:

Apesar de ao longo da história os recursos naturais terem sido utilizados de maneira desenfreada e sem nenhum tipo de cuidado, essa situação está redimensionada. O termo "sustentável" veio justamente no sentido de compatibilizar as ações humanas com a conservação do meio ambiente em que se vive, e preservá-lo para as gerações futuras. Neste contexto, o processo civilizatório exige a solução de problemas sociais, políticos, culturais e ambientais; e

16 Boff, descreve que o termo "Sustentabilidade", o dicionário possui 2 sentidos para o termo, um passivo e outro ativo. Sendo que o passivo se refere a "sustentar" como equilibrar-se, manter-se conversar-se sempre à mesma altura, conservar-se sempre bem. Já o termo ativo, enfatiza a ação feita de fora para conservar, manter, proteger, nutrir, alimentar, fazer prosperar, subsistir, viver. BOFF, Leonardo. Sustentabilidade: o que é - o que não é. 3. ed. Petrópolis - RJ: Vozes, 2014. P. 31-32.

17 BOFF, Leonardo: Sustentabilidade, o que é - O que não é. 3 ed. Petrópolis-RJ: Editora Vozes, 2014, p. 14.

18 BOSSELMANN, Klaus. O princípio da Sustentabilidade: transformando direito e governança. São Paulo: Revista dos Tribunais, 2015. p. 34. Tradução Phillip Gil França. Título Original: The Principle of sustainability. 
CARNeIRO, Cheila da Silva dos Passos. RODRIGUES, Patrícia Silva. PASOLD, Cesar Luiz. A transnacionalização da sustentabilidade no direito ambiental. Revista Eletrônica Direito e Política, Programa de Pós-Graduação Stricto Sensu em Ciência Jurídica da UNIVALI, Itajaí, v.11, n.2, 2o quadrimestre de 2016. Disponível em: www.univali.br/direitoepolitica - ISSN 1980-7791.

a Sustentabilidade surge como alternativa para que tal processo permanece em continuidade. ${ }^{19}$

Além dos conceitos apresentados, Zylbersztajn relata que a expressão é uma contradição em termos, pois "a noção de desenvolvimento envolve dinâmica e, portanto, movimento. Já a noção de sustentabilidade subentende uma situação estática, que pressupõe permanência."20

A meta de preservação do Meio Ambiente para as gerações futuras e o processo civilizatório se propõe como fator em constante evolução.

Varella discorre sobre os cenários em que o Desenvolvimento Sustentável e seu princípio é empregado:

O princípio do desenvolvimento sustentável vem da fusão de dois
grandes princípios jurídicos: o direito ao desenvolvimento e o da
preservação do Meio Ambiente. O primeiro é originário do direito
internacional econômico, mais especificadamente do direito do
desenvolvimento, um ramo do direito originado dos movimentos
de independência após a Segunda Guerra Mundial. O segundo vem
do direito ambiental, trabalhando, sobretudo, a partir dos anos
1970. ${ }^{21}$

Conforme o autor cita, a preservação e o desenvolvimento do Meio Ambiente caminham juntos. Além disso, os autores alertam que "os impactos ambientais atingiram dimensões globais e hoje a Natureza encontra-se em colapso, pois a Humanidade está diante de um limite de

19 AQUINO, Sérgio Ricardo Fernandes de; BASTIANI, Ana Cristina Bacega De: As Andarilhagens da Sustentabilidade no Século XXI. 1 ed. Florianópolis: Empório do Direito, 2015, p. 19.

20 ZYLBERSZTAJN, David. Sustentabilidade e geração de valor: a transição para o século XXI. Rio de Janeiro: Elsevier, 2010. p.1.

21 VARELLA, Marcelo Dias. Direito internacional econômico ambiental. Belo Horizonte: Del Rey, 2003. P. 5-6. 
CARNeIRO, Cheila da Silva dos Passos. RODRIGUES, Patrícia Silva. PASOLD, Cesar Luiz. A transnacionalização da sustentabilidade no direito ambiental. Revista Eletrônica Direito e Política, Programa de Pós-Graduação Stricto Sensu em Ciência Jurídica da UNIVALI, Itajaí, v.11, n.2, 2o quadrimestre de 2016. Disponível em: www.univali.br/direitoepolitica - ISSN 1980-7791.

crescimento, em razão do estilo de vida adotado."22 Boff ressalta que, "se olharmos à nossa volta, damo-nos conta do desequilíbrio que tomou conta do Sistema Terra e do Sistema Sociedade. Há um mal-estar cultural generalizado com a sensação de que imponderáveis catástrofes poderão acontecer a qualquer momento". 23

A importância de desenvolvimento da sustentabilidade é o fator vital para a Humanidade, inclusive Boff define, de acordo com as palavras da Carta da Terra, como questão de vida ou morte:

Pelas palavras da Carta da Terra, a sustentabilidade comparece
como uma questão de vida ou morte. Nunca antes da história
conhecida da civilização humana, corremos os riscos que
atualmente ameaçam nosso futuro comum. Esses riscos não
diminuem pelo fato de que muitíssimas pessoas, de todos os níveis
de saber, deem de ombros a esta máxima questão. O que não
podemos é, por descuido e ignorância, chegar tarde demais. Mais
vale o princípio da precaução e de prevenção do que a indiferença,
o cinismo e a despreocupação irresponsável. Se dermos
centralidade à aliança de cuidado, seguramente chegaremos a um
estágio de sustentabilidade geral que nos propiciará desafogo,
alegria de viver e esperança de mais história a construir rumo a
uma futuro mais promissor. ${ }^{24}$

No sistema atual, "há poucas palavras mais usadas hoje do que o substantivo sustentabilidade e o adjetivo sustentável. Pelos governos, pelas empresas, pela diplomacia e pelos meios de comunicação."25 Para isso é tão importante a conceituação correta da expressão.

22 AQUINO, Sérgio Ricardo Fernandes de; BASTIANI, Ana Cristina Bacega De: As Andarilhagens da Sustentabilidade no Século XXI. 1 ed. Florianópolis: Empório do Direito, 2015, p. 13.

${ }^{23}$ BOFF, Leonardo. Sustentabilidade: o que é - o que não é. 3. ed. Petrópolis - RJ: Vozes, 2014. p. 17.

${ }^{24}$ BOFF, Leonardo: Sustentabilidade: o que é - O que não é. 3. ed. Petrópolis - RJ: Vozes, 2014. p.14.

${ }^{25}$ BOFF, Leonardo: Sustentabilidade, o que é - O que não é. 3. ed. Petrópolis - RJ: Vozes, 2014. p. 9 
CARNeIRO, Cheila da Silva dos Passos. RODRIGUES, Patrícia Silva. PASOLD, Cesar Luiz. A transnacionalização da sustentabilidade no direito ambiental. Revista Eletrônica Direito e Política, Programa de Pós-Graduação Stricto Sensu em Ciência Jurídica da UNIVALI, Itajaí, v.11, n.2, 2o quadrimestre de 2016. Disponível em: www.univali.br/direitoepolitica - ISSN 1980-7791.

Em certos casos a palavra "sustentabilidade" é apenas "uma etiqueta que se procura colocar nos produtos e nos processos de sua confecção para agregar-Ihes valor." 26 No entanto, "o preço pago pelo desenvolvimento sem limites da Humanidade é a situação lamentável enfrentada nos dias de hoje." 27

Para prevenir esse resultado, Machado leciona que:

A precaução age no presente para não se ter que chorar e lastimar o futuro. A precaução não só deve estar presente para impedir o prejuízo ambiental, mesmo incerto, que possa resultar das ações ou omissões humanas, como deve atuar para a prevenção oportuna desse prejuízo. Evita-se o dano ambiental através da prevenção no tempo certo. ${ }^{28}$

Sobre o Princípio da Precaução, Guerra ensina que "[...] é aquele que determina que não se produzam intervenções no meio ambiente antes de se ter a certeza de que estas não serão adversas a ele." 29

Em relação ao Princípio da Prevenção Milaré cita que "o princípio da prevenção tem como objetivo impedir a ocorrência de danos ao meio ambiente, através da imposição de medidas acautelatórias, antes da implantação de empreendimentos e atividade consideradas efetiva ou potencialmente poluidoras."30 Fiorillo aduz que "é adotado diante da impotência do sistema jurídico de restabelecer em igualdade de condições uma situação idêntica à anterior, utilizando-se, então, da ideia de

${ }^{26}$ BOFF, Leonardo: Sustentabilidade, o que é - O que não é. 3. ed. Petrópolis - RJ: Vozes, 2014. p. 9.

${ }^{27}$ AQUINO, Sérgio Ricardo Fernandes de; BASTIANI, Ana Cristina Bacega De: As Andarilhagens da Sustentabilidade no Século XXI. p. 13.

28 MACHADO, Paulo Affonso Leme. Direito ambiental brasileiro. 9 ed. São Paulo: Malheiros, 2001, p. 57.

29 GUERRA, Sidney. Resíduos sólidos: comentários à Lei 12.305/2010. Rio de Janeiro: Forense, 2012, p. 102.

30 MILARÉ Edis. Direito do ambiente. 8 ed. São Paulo: RT, 2013. p. 263-264. 
CARNeIRO, Cheila da Silva dos Passos. RODRIGUES, Patrícia Silva. PASOLD, Cesar Luiz. A transnacionalização da sustentabilidade no direito ambiental. Revista Eletrônica Direito e Política, Programa de Pós-Graduação Stricto Sensu em Ciência Jurídica da UNIVALI, Itajaí, v.11, n.2, 2o quadrimestre de 2016. Disponível em: www.univali.br/direitoepolitica - ISSN 1980-7791.

prevenção de danos como sustentáculo do Direito Ambiental, consubstanciando-se como seu objetivo fundamental."31

Pois bem, é claro que ao tratar do termo Sustentabilidade, não se fala mais em comunidade local, sendo responsável todo aquele que desempenha um papel, significativo ou não, no senário da industrialização e consumismo, ou seja, "o agravamento da crise ocorreu a partir do final do século XIX, onde o meio ambiente tornou-se o centro de debates em todo mundo, diante da necessidade de uma postura que prolongue a vida do ser Humano na Terra."32 Atingindo a esfera global, surge a necessidade de uma Transnacionalização da Sustentabilidade.

\section{DA TRANSNACIONALIDADE DO DIREITO AMBIENTAL}

A Transnacionalidade, em uma definição literal da palavra, tem como objetivo ultrapassar fronteiras. Empregada ao contexto sustentável, detém o poder de expandir o pensamento da Sustentabilidade para a manutenção da vida. Na definição de Micol Seigel, a Transnacionalidade "examina unidades que se derramam e vazam através de fronteiras nacionais, unidades maiores e menores do que o Estado-nação"33.

A palavra "transnacional" assim como o fenômeno da Transnacionalização reflete a expansão através dos Estados, ou seja, a globalização. Stelzer traz o significado:

31 FIORILLO, Celso Antonio Pacheco. Cursos de direito ambiental brasileiro. 14. ed. São Paulo: Saraiva, 2013, p. 120.

32 AQUINO, Sérgio Ricardo Fernandes de; BASTIANI, Ana Cristina Bacega De: As Andarilhagens da Sustentabilidade no Século XXI. p. 13.

33 SEIGEL, Micol. Beyond Compare: Comparative Method after the Transnational Turn. Radical History Review, No 91, Winter, 2005. p. 62-90. 
CARNeIRO, Cheila da Silva dos Passos. RODRIGUES, Patrícia Silva. PASOLD, Cesar Luiz. A transnacionalização da sustentabilidade no direito ambiental. Revista Eletrônica Direito e Política, Programa de Pós-Graduação Stricto Sensu em Ciência Jurídica da UNIVALI, Itajaí, v.11, n.2, 2o quadrimestre de 2016. Disponível em: www.univali.br/direitoepolitica - ISSN 1980-7791.

O prefixo trans tem origem latina e significa "além de, através,
para trás, em troca de ou ao revés". No presente estudo,
"transnacional" é concebido como aquilo que atravessa o nacional,
que perpassa o Estado, que está além da concepção soberana do
Estado e, por conseqüência, que traz consigo, inclusive, a ausência
da dicotomia público e privado [...] A transnacionalização pode ser
compreendida como fenômeno reflexivo da globalização, que se
evidencia pela desterritorialização dos relacionamentos
políticosociais, fomentado por sistema econômico capitalista
ultravalorizado, que articula ordenamento jurídico mundial à
margem da soberania dos Estados. A transnacionalidade insere-se
no contexto da globalização e liga-se fortemente à concepção de
transpasse estatal. Enquanto globalização remete à ideia de
conjunto, de globo, enfim, o mundo sintetizado como único;
transnacionalização está atada à referência do Estado permeável,
mas tem na figura estatal a referência do ente em declínio ${ }^{34}$. A Transnacionalidade se movimenta através de fronteiras, fazendo surgir relações entre Estados, assim a Transnacionalidade "não é um fenômeno distinto da globalização ou mundialização, pois nasce no seu contexto, com características que podem viabilizar o surgimento da categoria Direito Transnacional."35 Ainda, Stelzer argumenta que Sustentabilidade "inserese no contexto da Globalização e liga-se fortemente à concepção do transpasse estatal."36

A ideia de Transnacionalização da Sustentabilidade está ligada ao conceito de tornar maleável a figura do Estado Soberano, relativizando-a para que ceda em prol da coletividade mundial, isso porque a proposta de sustentabilidade de nada adiantaria, se barreiras fossem erguidas. Destarte, esta proposta transnacional visa uma "Sociedade não-territorial, não-integrada, não-exclusiva, o que não quer dizer que esta forma de diversidade social e da diferença cultural não possui ou conhece nenhum

34 STELZER, Joana. Mercado Europeu: direito e análise jurisprudencial. Curitiba: Juruá, 2004.

35 STELZER. Joana. Direito e transnacionalidade. Curitiba: Juruá, 2011. p. 16 e 18.

${ }^{36}$ STELZER. Joana. Direito e transnacionalidade. Curitiba: Juruá, 2011. p. 21. 
CARNeIRO, Cheila da Silva dos Passos. RODRIGUES, Patrícia Silva. PASOLD, Cesar Luiz. A transnacionalização da sustentabilidade no direito ambiental. Revista Eletrônica Direito e Política, Programa de Pós-Graduação Stricto Sensu em Ciência Jurídica da UNIVALI, Itajaí, v.11, n.2, 2o quadrimestre de 2016. Disponível em: www.univali.br/direitoepolitica - ISSN 1980-7791.

vínculo local."37 Assim, existe uma aproximação social, a qual não pode ser impedida por barreiras geográficas ou espaciais.

\section{A QUEBRA DE FRONTEIRAS DA SUSTENTABILIDADE: A TRANSNACIONALIDADE}

A humanidade caminha rumo a uma Sociedade integrada, a tecnologia atual dispensa barreiras, e a comunicação já não possui limites. Ao empregar uma politica sustentável, a Transnacionalização tem papel importante a ser desempenhado.

De acordo com Cruz, "[...] o grande desafio para o Século XXI será a construção de uma Sociedade Democrática transnacional, respeitadora das diferentes concepções humanas, baseada na paz, na preservação da vida, na justiça social e no acesso de todos ao bem-estar". 38

A busca por uma Sociedade solidária fez interagir as mais diversas áreas, como a econômica, cultural, politica, entre outras, aproximando, assim, cada vez mais essa Sociedade global.

A Transnacionalização de Desenvolvimento Sustentável é mais um conceito e meta nova a ser buscada em escala mundial. Sobre a interação, Trindade argumenta que:

Embora tenham os domínios da proteção do ser humano e da proteção ambiental sido tratados até o presente separadamente, é necessário buscar maior aproximação entre eles, porquanto

37 BECK, Ulrich. O que é globalização? Equívocos do globalismo: resposta à globalização. Tradução de André Carone. São Paulo: Terra e Paz, 1999. p. 185.

38 CRUZ, Paulo Márcio. Repensar a Democracia. Revista jurídica FURB. Blumenau, v. 13. 2009. p. 21. 
CARNEIRO, Cheila da Silva dos Passos. RODRIGUES, Patrícia Silva. PASOLD, Cesar Luiz. A transnacionalização da sustentabilidade no direito ambiental. Revista Eletrônica Direito e Política, Programa de Pós-Graduação Stricto Sensu em Ciência Jurídica da UNIVALI, Itajaí, v.11, n.2, 2o quadrimestre de 2016. Disponível em: www.univali.br/direitoepolitica - ISSN 1980-7791.

correspondem aos principais desafios de nosso tempo, a afetarem em última análise os rumos e destinos do gênero humano. ${ }^{39}$

Exercer uma Democracia Ambiental é, como ressalta Paulo de Bessa Antunes, assegurar aos cidadãos o direito de participar da construção de um país sustentável e o Estado Democrático:

O princípio democrático é aquele que assegura aos cidadãos o direito pleno de participar na elaboração das políticas públicas ambientais. E tal participação, em nível nacional, ocorre de diversas formas, como, por exemplo, o dever jurídico de proteger e preservar o meio-ambiente; o direito de opinar sobre as políticas públicas, por meio da participação em audiências públicas; o uso de mecanismos judiciais e administrativos de controle dos diferentes atos praticados pelos Executivos; as iniciativas legislativas que podem ser patrocinadas pelos cidadãos. ${ }^{40}$

Sobre a implantação da Transnacionalidade, "o Estado ainda é o principal protetor destes direitos, mas agora, a comunidade internacional passou a reagir frente a eventuais abusos cometidos."41 Cabe, portanto, a cada um dos seres humanos a implantação de costumes sustentáveis, porém, ao Estado cabe a Judicialização da Política Sustentável.

\section{JUDICIALIZAÇÃO DA SUSTENTABILIDADE TRANSNACIONALIZAÇÃO}

A partir da definição de Sustentabilidade e Transnacionalização, observase uma demanda por instrumentos que assegurem a sua aplicação. Afinal, a maior busca da humanidade é a garantia dos direitos humanos, e o maior expoente do momento é garantir uma vida em equilíbrio com o

39 TRINDADE, Antônio Augusto Cançado. Direitos humanos e meio ambiente: paralelo dos sistemas de proteção internacional. Porto Alegre: Sérgio Antônio Fabris Editor, 1993, p. 23.

40 ANTUNES, Paulo de Bessa. Direito ambiental. 9 ed. Rio de Janeiro: Lumen Juris Editora, 2006. P. 33.

41 AQUINO, Sérgio Ricardo Fernandes de; BASTIANI, Ana Cristina Bacega De: As Andarilhagens da Sustentabilidade no Século XXI. p.15. 
CARNeIRO, Cheila da Silva dos Passos. RODRIGUES, Patrícia Silva. PASOLD, Cesar Luiz. A transnacionalização da sustentabilidade no direito ambiental. Revista Eletrônica Direito e Política, Programa de Pós-Graduação Stricto Sensu em Ciência Jurídica da UNIVALI, Itajaí, v.11, n.2, 2o quadrimestre de 2016. Disponível em: www.univali.br/direitoepolitica - ISSN 1980-7791.

meio ambiente e um estado de bem-estar. A positivação de normas possui "o condão de conservar, preservar e proteger o direito humano e fundamental ao meio ambiente" 42 Schwenck ressalta a relação buscada com esse equilíbrio e efetivação das normas:

\begin{abstract}
Pode-se afirmar que a relação se centra em dois aspectos: em um primeiro momento, a proteção do meio ambiente como forma de se conseguir o cumprimento dos direitos humanos, vez que o entorno ambiental, se lesado, contribui diretamente para a infração de direitos reconhecidos internacionalmente, como o direito à vida, à saúde, ao bem-estar, ao desenvolvimento sustentado. $\mathrm{E}$, em um segundo momento, os direitos ambientais dependem do exercício dos direitos humanos para se efetivarem. Através do direito à informação, à liberdade de expressão, à tutela judicial, à participação política no Estado em que vive, enfim, no exercício da cidadania, poder-se-á reivindicar direitos relativos ao meio ambiente. ${ }^{43}$
\end{abstract}

Sobre a participação da coletividade, o artigo $1^{0}$ da Lei no 9795/1999,

Política Nacional de Educação Ambiental, apresenta o conceito para Educação Ambiental:

Processos por meio dos quais o indivíduo e a coletividade constroem valores sociais, conhecimentos, habilidades, atitudes e competências voltadas para a conservação do meio ambiente, bem de uso comum do povo, essencial à sadia qualidade de vida e sua sustentabilidade. ${ }^{4}$

Importante salientar que, além de leis esparsas, o Direito Ambiental se faz presente inclusive na Carta Magna, representando a importância que o país dá aos princípios e normas de preservação ambiental.

\title{
4.1 CONSTITUCIONALIZAÇÃO DA SUSTENTABILIDADE
}

42 AQUINO, Sérgio Ricardo Fernandes de; BASTIANI, Ana Cristina Bacega De: As Andarilhagens da Sustentabilidade no Século XXI. p. 18.

43 SCHWENCK, Terezinha. Direitos Humanos Ambientais. Disponível em: http://www.fadipa.br/pdf/schwenck.pdf. Acesso em 06 maio 2016.

${ }^{44}$ BRASIL. Senado Federal. Código Civil Brasileiro de 2002. Brasília. Disponível em: $<$ http://www.planalto.g ov.br/ccivil 03/leis/l9795.htm>. Acesso em 05 de maio de 2016. 
CARNeIRO, Cheila da Silva dos Passos. RODRIGUES, Patrícia Silva. PASOLD, Cesar Luiz. A transnacionalização da sustentabilidade no direito ambiental. Revista Eletrônica Direito e Política, Programa de Pós-Graduação Stricto Sensu em Ciência Jurídica da UNIVALI, Itajaí, v.11, n.2, 2o quadrimestre de 2016. Disponível em: www.univali.br/direitoepolitica - ISSN 1980-7791.

A Sustentabilidade está sendo cada vez mais incluída em textos legais. "O meio ambiente, como direito humano e fundamental previsto em Constituição já é uma realidade nos dias atuais. Há disposições constitucionais nesse sentido em diversos países, inclusive no Brasil."45 Sobre o objetivo do Direito Ambiental, Séguin discorre:

O objetivo do direito ambiental é a harmonização da natureza, garantida pela manutenção dos ecossistemas e da sadia qualidade de vida para que o homem possa se desenvolver plenamente. Restaurar, conservar e preservar são metas a serem alcançadas através desse ramo do Direito, com a participação popular. ${ }^{46}$

A própria Constituição da República Federativa do Brasil de 1988 prevê, em seu artigo 225, que "todos têm direito ao meio ambiente ecologicamente equilibrado, bem de uso comum do povo e essencial à sadia qualidade de vida, impondo-se ao Poder Público e à coletividade o dever de defendê-lo e preservá-lo para as presentes e futuras gerações."47 Ainda, são diversos os artigos que demonstram a preocupação do legislador com o Meio Ambiente. ${ }^{48}$ Admitindo que em um

45 AQUINO, Sérgio Ricardo Fernandes de; BASTIANI, Ana Cristina Bacega De: As Andarilhagens da Sustentabilidade no Século XXI. p. 18.

46 SÉGUIN, Elida. O direito ambiental: nossa casa planetária. 2 ed. Rio de Janeiro: Forense, 2002, p. 89.

47 Constituição da República Federativa do Brasil de 1988. <http://www.planalto.gov.br/ccivil 03/constituicao/constituicaocompilado.htm > Acesso em: 10 de abril de 2016.

${ }^{48}$ Art. 50. [...].LXXIII - qualquer cidadão é parte legítima para propor ação popular que vise a anular ato lesivo ao patrimônio público ou de entidade de que o Estado participe, à moralidade administrativa, ao meio ambiente e ao patrimônio histórico e cultural, ficando o autor, salvo comprovada má-fé, isento de custas judiciais e do ônus da sucumbência; Art. 23. É competência comum da União, dos Estados, do Distrito Federal e dos Municípios: [...]. VI - proteger o meio ambiente e combater a poluição em qualquer de suas formas; VII - preservar as florestas, a fauna e a flora; Art. 24. Compete à União, aos Estados e ao Distrito Federal legislar concorrentemente sobre: VI - florestas, caça, pesca, fauna, conservação da natureza, defesa do solo e dos recursos naturais, proteção do meio ambiente e controle da poluição; VII - proteção ao patrimônio histórico, cultural, artístico, turístico e paisagístico; VIII - responsabilidade por dano ao meio ambiente, ao consumidor, a bens e direitos de valor artístico, 
CARNEIRO, Cheila da Silva dos Passos. RODRIGUES, Patrícia Silva. PASOLD, Cesar Luiz. A transnacionalização da sustentabilidade no direito ambiental. Revista Eletrônica Direito e Política, Programa de Pós-Graduação Stricto Sensu em Ciência Jurídica da UNIVALI, Itajaí, v.11, n.2, 2o quadrimestre de 2016. Disponível em: www.univali.br/direitoepolitica - ISSN 1980-7791.

estético, histórico, turístico e paisagístico; [...] Art. 170. A ordem econômica, fundada na valorização do trabalho humano e na livre iniciativa, tem por fim assegurar a todos existência digna, conforme os ditames da justiça social, observados os seguintes princípios: [...]. VI - defesa do meio ambiente, inclusive mediante tratamento diferenciado conforme o impacto ambiental dos produtos e serviços e de seus processos de elaboração e prestação; (Redação dada pela Emenda Constitucional no 42, de 19.12.2003). Art. 174. Como agente normativo e regulador da atividade econômica, o Estado exercerá, na forma da lei, as funções de fiscalização, incentivo e planejamento, sendo este determinante para o setor público e indicativo para o setor privado. [...]. $\S$ 30 - O Estado favorecerá a organização da atividade garimpeira em cooperativas, levando em conta a proteção do meio ambiente e a promoção econômico-social dos garimpeiros. Art. 186. A função social é cumprida quando a propriedade rural atende, simultaneamente, segundo critérios e graus de exigência estabelecidos em lei, aos seguintes requisitos: [...]. II - utilização adequada dos recursos naturais disponíveis e preservação do meio ambiente;[...] Art. 200. Ao sistema único de saúde compete, além de outras atribuições, nos termos da lei: [...]. VIII - colaborar na proteção do meio ambiente, nele compreendido o do trabalho. [...] Art. 220. A manifestação do pensamento, a criação, a expressão e a informação, sob qualquer forma, processo ou veículo não sofrerão qualquer restrição, observado o disposto nesta Constituição. [...]. II - estabelecer os meios legais que garantam à pessoa e à família a possibilidade de se defenderem de programas ou programações de rádio e televisão que contrariem o disposto no art. 221, bem como da propaganda de produtos, práticas e serviços que possam ser nocivos à saúde e ao meio ambiente.[...] Art. 225. Todos têm direito ao meio ambiente ecologicamente equilibrado, bem de uso comum do povo e essencial à sadia qualidade de vida, impondo-se ao Poder Público e à coletividade o dever de defendê-lo e preservá- lo para as presentes e futuras gerações. $\S 10$ Para assegurar a efetividade desse direito, incumbe ao Poder Público: I - preservar e restaurar os processos ecológicos essenciais e prover o manejo ecológico das espécies e ecossistemas; II - preservar a diversidade e a integridade do patrimônio genético do País e fiscalizar as entidades dedicadas à pesquisa e manipulação de material genético; III - definir, em todas as unidades da Federação, espaços territoriais e seus componentes a serem especialmente protegidos, sendo a alteração e a supressão permitidas somente através de lei, vedada qualquer utilização que comprometa a integridade dos atributos que justifiquem sua proteção; IV - exigir, na forma da lei, para instalação de obra ou atividade potencialmente causadora de significativa degradação do meio ambiente, estudo prévio de impacto ambiental, a que se dará publicidade; V - controlar a produção, a comercialização e o emprego de técnicas, métodos e substâncias que comportem risco para a vida, a qualidade de vida e o meio ambiente; VI - promover a educação ambiental em todos os níveis de ensino e a conscientização pública para a preservação do meio ambiente; VII - proteger a fauna e a flora, vedadas, na forma da lei, as práticas que coloquem em risco sua função ecológica, provoquem a extinção de espécies ou submetam os animais a crueldade. $\S$ $2^{\circ}$ Aquele que explorar recursos minerais fica obrigado a recuperar o meio ambiente degradado, de acordo com solução técnica exigida pelo órgão público competente, na forma da lei. $\S 30$ As condutas e atividades consideradas lesivas ao meio ambiente sujeitarão os infratores, pessoas físicas ou jurídicas, a sanções penais e administrativas, independentemente da obrigação de reparar os danos causados. $\S 4^{\circ}$ A Floresta Amazônica brasileira, a Mata Atlântica, a Serra do Mar, o Pantanal Mato- 
CARNeIRO, Cheila da Silva dos Passos. RODRIGUES, Patrícia Silva. PASOLD, Cesar Luiz. A transnacionalização da sustentabilidade no direito ambiental. Revista Eletrônica Direito e Política, Programa de Pós-Graduação Stricto Sensu em Ciência Jurídica da UNIVALI, Itajaí, v.11, n.2, 2o quadrimestre de 2016. Disponível em: www.univali.br/direitoepolitica - ISSN 1980-7791.

país democrático "é possível perceber que os direitos humanos são interpretados como direitos vinculados à própria pessoa, que constituem o núcleo jurídico da vida humana e das relações necessárias para viver em dignidade." 49

A constitucionalização do Princípio da Sustentabilidade é descrito por Aquino como:

A mudança de pensamento e de consciência, a fim de preservar, conservar e proteger a Natureza, é um grande passo que pode ser dado pela Humanidade para prolongação de sua própria existência neste planeta, já que a exploração do meio ambiente é uma realidade ainda nos dias de hoje. Com efeito, medidas estão sendo tomadas para amenizar o impacto negativo desta ação do Homem. Uma delas é o fenômeno da constitucionalização do princípio da Sustentabilidade. ${ }^{50}$

Freitas também discorre sobre o princípio constitucional da Sustentabilidade:

Trata-se do princípio constitucional que determina, com eficácia direta e imediata, a responsabilidade do Estado e da sociedade pela concretização solidária do desenvolvimento material e imaterial, socialmente inclusivo, durável e equânime, ambientalmente limpo, inovador, ético e eficiente, no intuito de assegurar, preferencialmente de modo preventivo e precavido, no presente e no futuro, o direito ao bem-estar. [...] Ou, numa fórmula sintética: é o princípio constitucional que determina

Grossense e a Zona Costeira são patrimônio nacional, e sua utilização far-se-á, na forma da lei, dentro de condições que assegurem a preservação do meio ambiente, inclusive quanto ao uso dos recursos naturais. $\S 50$ São indisponíveis as terras devolutas ou arrecadadas pelos Estados, por ações discriminatórias, necessárias à proteção dos ecossistemas naturais. $\S 6^{\circ}$ As usinas que operem com reator nuclear deverão ter sua localização definida em lei federal, sem o que não poderão ser instaladas.. [...].BRASIL. Constituição da República Federativa do Brasil (1988). Disponível

<http://www.planalto.gov.br/ccivil_03/constituicao/ConstituicaoCompilado.htm.>

em:

Acesso em: 10 de abril de 2016.

49 AQUINO, Sérgio Ricardo Fernandes de; BASTIANI, Ana Cristina Bacega De: As

Andarilhagens da Sustentabilidade no Século XXI. p. 17.

50 AQUINO, Sérgio Ricardo Fernandes de; BASTIANI, Ana Cristina Bacega De: As Andarilhagens da Sustentabilidade no Século XXI. p. 14. 
CARNeIRO, Cheila da Silva dos Passos. RODRIGUES, Patrícia Silva. PASOLD, Cesar Luiz. A transnacionalização da sustentabilidade no direito ambiental. Revista Eletrônica Direito e Política, Programa de Pós-Graduação Stricto Sensu em Ciência Jurídica da UNIVALI, Itajaí, v.11, n.2, 2o quadrimestre de 2016. Disponível em: www.univali.br/direitoepolitica - ISSN 1980-7791.

promover o desenvolvimento social, econômico, ambiental, ético e jurídico-politico, no intuito de assegurar as condições favoráveis para o bem-estar das gerações presentes e futuras.

Sobre a questão ambiental na Constituição da República Federativa do Brasil, Miranda cita que:

As Constituições, com o desenvolvimento da questão ambiental, deram um salto para incluir a noção da sadia qualidade de vida. A vida a ser protegida engloba agora o aspecto da vida saudável, e esta salubridade não se contrapõe simplesmente à ausência de doença, pelo contrário, leva em conta pelo menos três fatores que proporcionaram o tão almejado desenvolvimento: saúde, educação e produto interno bruto. ${ }^{51}$

Dando força ao Princípio da Sustentabilidade, encontra-se presente na Constituição da República Federativa do Brasil, o Princípio da Solidariedade, também relativo ao Direito Ambiental. Para Fensterseifer, "o princípio da solidariedade também aparece consubstanciado no Preâmbulo da Constituição da República Federativa do Brasil ao estabelecer que os direitos sociais e individuais, a liberdade, a segurança, o bem-estar, o desenvolvimento, a igualdade e a justiça como valores supremos de uma sociedade fraterna." 52

Além da inclusão de princípios ambientais na Constituição da República Federativa do Brasil, as ações coletivas e a participação em Políticas de Desenvolvimento Sustentável são o impulso para a vida sustentável em comunidade. Segundo Aquino:

Pode-se afirmar que a efetivação de um sistema democrático deve
ser um dos objetivos do desenvolvimento, uma vez que a
participação da sociedade através de processos de discussão,
escolhas e deliberações pode contribuir eficazmente para a
realização dos direitos humanos e fundamentais e também de

51 MIRANDA, Robinson Nicácio de. Direito ambiental. São Paulo: Rideel, 2009. p. 29.

52 FENSTERSEIFER, Tiago. Direitos fundamentais e proteção do ambiente: a dimensão ecológica da dignidade humana no marco jurídico constitucional do estado socioambiental de direito. Porto Alegre: Livraria do Advogado, 2008. p. 113 
CARNeIRO, Cheila da Silva dos Passos. RODRIGUES, Patrícia Silva. PASOLD, Cesar Luiz. A transnacionalização da sustentabilidade no direito ambiental. Revista Eletrônica Direito e Política, Programa de Pós-Graduação Stricto Sensu em Ciência Jurídica da UNIVALI, Itajaí, v.11, n.2, 20 quadrimestre de 2016. Disponível em: www.univali.br/direitoepolitica - ISSN 1980-7791.

políticas que resultem em melhores condições de vida para a comunidade mundial. A proteção aos direitos humanos e fundamentais, a participação na política, a associação com seus pares e a autonomia individual e coletiva são exemplos de ações positivas nesta caminhada rumo ao futuro, incerto e desconhecido. E cabe ao homem impulsionar estas condições, já que é o agente da transformação social. ${ }^{53}$

Como agente da transformação social, cabe preservar o meio em que vive para si próprio e para as futuras gerações. Inclusive, a Constituição da República Federativa do Brasil altera o sujeito de direito, dando direto àquele que ainda não foi concebido, agora o sujeito de direito são as gerações futuras. Esse é "o novo paradigma da Sustentabilidade é um conceito moderno que direciona o pensamento do presente para o futuro." 54

Como consequência da aplicação de normas de cunho ambiental na Constituição da República Federativa do Brasil, Derani apresenta:

A proteção constitucional do meio ambiente traz, fundamentalmente, as seguintes conseqüências: A partir do momento em que ganha o caráter de norma constitucional, o direito ao meio ambiente ecologicamente equilibrado torna-se um "bem jurídico" que deve ser igualmente correlacionado com os demais "bens jurídicos" presentes na Constituição. Portanto, é igualmente um desdobramento do art. 32 da CF e deve ser revelado na atuação privada como na estatal com a mesma prioridade das demais normas da Constituição Federal. As bases naturais da vida, ao serem reconhecidas como bens constitucionais, espelham a sua real importância como fator estrutural e conformador de uma sociedade. A declaração da proteção ambiental como um objetivo do Estado e um dever da coletividade desempenha importante papel na formação da

53 AQUINO, Sérgio Ricardo Fernandes de; BASTIANI, Ana Cristina Bacega De: As Andarilhagens da Sustentabilidade no Século XXI. p. 20.

54 AQUINO, Sérgio Ricardo Fernandes de; BASTIANI, Ana Cristina Bacega De: As Andarilhagens da Sustentabilidade no Século XXI. p. 19. 
CARNeIRO, Cheila da Silva dos Passos. RODRIGUES, Patrícia Silva. PASOLD, Cesar Luiz. A transnacionalização da sustentabilidade no direito ambiental. Revista Eletrônica Direito e Política, Programa de Pós-Graduação Stricto Sensu em Ciência Jurídica da UNIVALI, Itajaí, v.11, n.2, 2o quadrimestre de 2016. Disponível em: www.univali.br/direitoepolitica - ISSN 1980-7791.

consciência social, por uma responsabilidade conjunta para com este bem. ${ }^{55}$

A implantação de questões ambientais em textos constitucionais é premissa da preocupação do Estado com a sua manutenção, logo, não se preserva somente a água que banha o seu rio, mas toda a nascente acima dele, com isso, percebeu-se a necessidade de uma visão mais global, uma Transnacionalização da Sustentabilidade e dos conceitos de preservação do Meio Ambiente. Não é responsável o Estado somente até onde alcança a sua jurisdição, mas muito mais além desta.

\subsection{A Transnacionalização Sustentável}

Presente em tratados internacionais é possível perceber, se traçada uma linha evolutiva da proteção jurídica ambiental, de mecanismos que visaram a garantira a efetivação de um Direito Ambiental, em nível internacional, tem-se exemplos como as Declarações de Estocolmo de 1972 e do Rio de Janeiro de 1992. Antes ainda, presente na Convenção de Montego Bay de 1982, dentre outras.

O início da presença internacional do Direito Ambiental e da Sustentabilidade em textos constitucionais traz a "intensificação das relações sociais em escala mundial." ${ }^{56}$ Sobre isso, Aquino destaca o início da positivação:

O surgimento do Estado Moderno foi consolidado após as reflexões políticas-filosóficas do século XVII e o capitalismo. Este avanço histórico possibilitou a positivação dos direitos humanos através de textos normativos capazes de regular a relação entre o indivíduo e - Estado. A origem dessa positivação foram as revoluções que

55 DERANI, Cristiane. Direito Ambiental Econômico. 3 ed. São Paulo: Saraiva, 2008, p. 257.

${ }^{56}$ GIDDENS, Antony. As consequências da modernidade. Tradução de Raul Fiker. São Paulo: Editora UNESP. Título Original: The consequences of modernity.1991. p. 69. 
CARNeIRO, Cheila da Silva dos Passos. RODRIGUES, Patrícia Silva. PASOLD, Cesar Luiz. A transnacionalização da sustentabilidade no direito ambiental. Revista Eletrônica Direito e Política, Programa de Pós-Graduação Stricto Sensu em Ciência Jurídica da UNIVALI, Itajaí, v.11, n.2, 2o quadrimestre de 2016. Disponível em: www.univali.br/direitoepolitica - ISSN 1980-7791.

resultaram nas Declarações de Direito - inicialmente na França e nos Estados Unidos - e logo e espalharam pelo mundo. O que antes eram Declarações de Direitos passaram a ser textos constitucionais, como a Constituição Mexicana (1917) e a Constituição da República de Weimar (1919), por exemplo. Direitos individuais, humanos (em âmbito internacional) e de liberdade passaram a prevalecer na ordem interna e externa, já que o Estado Moderno refere-se ao homem como indivíduo e não mais como membro de clã, família, aldeia, etc. ${ }^{57}$

Exemplo mais próximo tem-se a Conferência das Nações Unidas sobre Desenvolvimento Sustentável, realizada no Rio de Janeiro, em junho de 2012, conhecida como Rio+20, cujo objetivo principal foi o de renovar compromissos políticos com o Desenvolvimento Sustentável.

Empregada cada vez mais em textos constitucionais e presente em tratados, a Transnacionalização da Sustentabilidade é fator importante no emprego das normas ambientais, bastando tão somente seu aprimoramento, cumprimento, fiscalização e punição caso não cumpridas. Nesse ponto, convém questionar de quem seria a responsabilidade pelo não cumprimento de tais normas.

\subsection{RESPONSABILIDADE DA TRANSNACIONALIZAÇÃO E IMPLANTAÇÃO DA SUSTENTABILIDADE.}

O meio ambiente como patrimônio da humanidade deve ser resguardado, afinal, é direito de todos um meio ambiente equilibrado. Trindade ressalta a importância da "salvaguarda do direito à vida de todas as pessoas, assim como das coletividades humanas, com especial atenção às

57 AQUINO, Sérgio Ricardo Fernandes de; BASTIANI, Ana Cristina Bacega De: As Andarilhagens da Sustentabilidade no Século XXI. p.15. 
CARNeIRO, Cheila da Silva dos Passos. RODRIGUES, Patrícia Silva. PASOLD, Cesar Luiz. A transnacionalização da sustentabilidade no direito ambiental. Revista Eletrônica Direito e Política, Programa de Pós-Graduação Stricto Sensu em Ciência Jurídica da UNIVALI, Itajaí, v.11, n.2, 20 quadrimestre de 2016. Disponível em: www.univali.br/direitoepolitica - ISSN 1980-7791.

exigências da sobrevivência dos grupos vulneráveis, como os pobres e desamparados $[\ldots]^{\prime \prime} .58$

Preservar o direito à vida também é dever do Estado, Aquino já descrevia esta conduta por parte da Sociedade e do Poder Público:

O bem comum deve ser entendido como fator relevante a vida
humana. Para que isso ocorra o sentimento de pertença a um lar é
fatos ímpar. Uma série de posturas deve ser tomada, e devem
partir tanto da Sociedade quanto do Poder Público. Ações
individuais mais conscientes e responsáveis são, de fato, o que
podem transformar esta realidade individualista em prol do direito
a um meio ambiente saudável, essencialmente à vida humana de
uma forma geral. Sob esta perspectiva, o Direito e a Constituição
auxiliariam neste processo. ${ }^{59}$

Afinal, "para que o desenvolvimento seja sustentável, não basta que seja ecologicamente sustentável, mas deve visar igualmente às dimensões sociais, econômicas, políticas e culturais do desenvolvimento"60. No mesmo sentido, Silva discorre:

A qualidade do meio ambiente transforma-se, assim, num bem ou patrimônio, cuja preservação, recuperação ou revitalização se tornaram um imperativo do poder público, para assegurar uma boa qualidade de vida, que implica boas condições de trabalho, lazer, educação, saúde, segurança - enfim, boas condições de bem-estar do Homem e de seu desenvolvimento. ${ }^{61}$

A responsabilidade estatal citada por Silva também é motivo de debate para Gregorio Peces-Barba, apesar da abordagem muito mais sutil e

58 TRINDADE, Antônio Augusto Cançado. Direitos humanos e meio ambiente: paralelo dos sistemas de proteção internacional. Porto Alegre: Sérgio Antônio Fabris Editor, 1993, p. 75.

59 AQUINO, Sérgio Ricardo Fernandes de; BASTIANI, Ana Cristina Bacega De: As Andarilhagens da Sustentabilidade no Século XXI. p. 25.

60 SILVA, Geraldo Eulálio do Nascimento. Direito Ambiental Internacional. 2. ed. Rio de Janeiro: Thex Ed., 2002.p. 50.

61 SILVA, José Afonso da. Direito ambiental constitucional. 3 ed. São Paulo: Malheiros Editores, 2002, p. 24. 
CARNeIRO, Cheila da Silva dos Passos. RODRIGUES, Patrícia Silva. PASOLD, Cesar Luiz. A transnacionalização da sustentabilidade no direito ambiental. Revista Eletrônica Direito e Política, Programa de Pós-Graduação Stricto Sensu em Ciência Jurídica da UNIVALI, Itajaí, v.11, n.2, 2o quadrimestre de 2016. Disponível em: www.univali.br/direitoepolitica - ISSN 1980-7791.

divisão das responsabilidades para com a comunidade e sua participação na tomada de decisões:

Ciudadanía representa el vínculo que une a una persona con un Estado; es el vínculo radical entre esta y la organización política y jurídica a la que pertenece. [...] es el resultado del paso de creyente y de súbdito como vínculo fundamental y excluyente del orden al que está sometida la persona al de ciudadano, en el marco de una organización política liberal donde la persona tiene derechos, y participa directamente o por represetación en la formación del poder político. [...] Ser ciudadano significa poder ejercer con garantía jurídica y política una serie de derechos humanos básicos y fundamentales y tener ciertos deberes políticos y jurídicos. ${ }^{62}$

Afinal a "Sustentabilidade é um modo de ser e de viver que exige alinhar as práticas humanas às potencialidades limitadas de cada bioma e às necessidades da presente e das futuras gerações."63 Logo, a responsabilidade é de todos.

Sobre a responsabilidade do Estado, Derani argumenta que "o exercício do Poder Público manifesta-se, sobretudo, na participação das atividades sociais, resguardando-as da ambição individual." Ou seja, "a finalidade do Estado não é apenas a de assegurar a liberdade individual e a proteção da propriedade privada, porém, através desta unificação, permitir que o

62 PECES-BARBA, Gregorio. Educación para la ciudadanía y derechos humanos. p. 310-311. Tradução livre das autoras: Cidadania representa a ligação que une uma pessoa com o Estado; é o vínculo radical entre esta e a organização política e jurídica à que pertence. [...] é o resultado do passo do crente e do súdito como vínculo fundamental e excludente da ordem à que está submetida a pessoa ao de cidadão, no marco de uma organização política liberal onde a pessoa tem direitos, e participa diretamente ou por representação na formação do poder político. [...] Ser cidadão significa poder exercer com garantia jurídica e política uma série de direitos humanos básicos e fundamentais e possuir certos deveres políticos e jurídicos.

63 BOFF, Leonardo: Sustentabilidade, o que é - O que não é. 3. ed. Petrópolis - RJ: Vozes, 2014, p.16. 
CARNeIRO, Cheila da Silva dos Passos. RODRIGUES, Patrícia Silva. PASOLD, Cesar Luiz. A transnacionalização da sustentabilidade no direito ambiental. Revista Eletrônica Direito e Política, Programa de Pós-Graduação Stricto Sensu em Ciência Jurídica da UNIVALI, Itajaí, v.11, n.2, 2o quadrimestre de 2016. Disponível em: www.univali.br/direitoepolitica - ISSN 1980-7791.

indivíduo consiga obter um tipo de existência que ele isoladamente jamais alcançaria. "64

Não é somente um poder do Estado, mas um dever, afinal, "a prática deste poder impõe-se como um dever do Estado, por isso sua característica de um dever que se reveste em poder."65

Além da responsabilidade de preservação, outro conceito importante como mecanismo de preservação é a punição, afinal, nem todos possuem consciência de que preservar é preciso, cumprindo metas apenas se lhes for obrigado, eis que surge o inicio da teoria do poluidor pagador.

O Princípio do Poluidor Pagador, "visa à internalização dos custos relativos externos de deterioração ambiental."66 Sobre a consciência e a responsabilidade do poluidor pagador, Fiorillo ensina que:

Num primeiro momento, impõem-se ao poluidor o dever de arcar com as despesas de prevenção dos danos ao meio ambiente que a sua atividade possa ocasionar. Cabe a ele o ônus de utilizar instrumentos necessários à prevenção dos danos. Numa segunda órbita de alcance, esclarece este princípio que, ocorrendo danos ao meio ambiente em razão da atividade desenvolvida, o poluidor será responsável pela sua reparação. ${ }^{67}$

Afinal:

Constata-se que os recursos ambientais não são inesgotáveis, tornando-se inadmissível que as atividades econômicas desenvolvam-se alheias a esse fato. Busca-se com isso a coexistência harmônica entre economia e meio ambiente. Permite-

64 DERANI, Cristiane. Direito Ambiental Econômico. 3 ed. São Paulo: Saraiva, 2008, p. 254.

65 DERANI, Cristiane. Direito Ambiental Econômico. 3 ed. São Paulo: Saraiva, 2008, p. 254.

${ }^{6}$ DERANI, Cristiane. Direito Ambiental Econômico. 3 ed. São Paulo: Saraiva, 2008, p. 142.

67 FIORILLO, Celso Antonio Pacheco. Curso de direito ambiental brasileiro. 7 ed. São Paulo: Saraiva, 2006, p. 30. 
CARNeIRO, Cheila da Silva dos Passos. RODRIGUES, Patrícia Silva. PASOLD, Cesar Luiz. A transnacionalização da sustentabilidade no direito ambiental. Revista Eletrônica Direito e Política, Programa de Pós-Graduação Stricto Sensu em Ciência Jurídica da UNIVALI, Itajaí, v.11, n.2, 2o quadrimestre de 2016. Disponível em: www.univali.br/direitoepolitica - ISSN 1980-7791.

se o desenvolvimento, mas de forma sustentável, planejada, para que os recursos hoje existentes não se esgotem ou tornem-se inócuos. ${ }^{68}$

Nas palavras de Lemos, este cita que o princípio prevê que "[...] 0 causador da poluição arcará com seus custos, o que significa dizer que ele responde pelas despesas de prevenção, reparação e repressão da poluição."69 Ou seja, "o que se busca com tal princípio é que os custos das medidas de proteção ao meio ambiente sejam internalizados no custo de produção, repercutindo nos custos finais de produtos e serviços cuja produção agrida o meio ambiente."70

Nas palavras de Derani, o "princípio do poluidor-pagador, arca o causador da poluição com os custos necessários à diminuição, eliminação ou neutralização deste dano." Ou seja, "Ele pode, desde que isso seja compatível com as condições da concorrência no mercado, transferir estes custos para o preço do seu produto final."71

A consciência da preservação, quando não adotada de forma natural, deve ser imposta a quem não respeita os limites estabelecidos para a preservação do próprio ser. Fato de destaque nos dias atuais é que os chefes de Estado das nações mais ricas, personagens vitais na implementação deste sistema, parecem não perceber a importância de uma política solidária, fraterna e sustentável. Boff já descrevia que "o

68 FIORILLO, Celso Antonio Pacheco. Curso de direito ambiental brasileiro. 7 ed. São Paulo: Saraiva, 2006, p. 27.

69 LEMOS, Patrícia Faga Iglesias. Resíduos sólidos e responsabilidade civil pósconsumo. São Paulo: Revista dos Tribunais, 2011, p. 56-57.

70 GARCIA, Heloise Siqueira. Avaliação ambiental estratégica e política nacional de resíduos sólidos: uma análise da aplicação em suas ações estratégicas no contexto do Brasil e da Espanha. 1 ed. Florianópolis: Empório do Direito, 2015, p. 78.

71 DERANI, Cristiane. Direito Ambiental Econômico. 3 ed. São Paulo: Saraiva, 2008. p. 143. 
CARNeIRO, Cheila da Silva dos Passos. RODRIGUES, Patrícia Silva. PASOLD, Cesar Luiz. A transnacionalização da sustentabilidade no direito ambiental. Revista Eletrônica Direito e Política, Programa de Pós-Graduação Stricto Sensu em Ciência Jurídica da UNIVALI, Itajaí, v.11, n.2, 2o quadrimestre de 2016. Disponível em: www.univali.br/direitoepolitica - ISSN 1980-7791.

grau de humanidade de um grupo humano se avalia pelo nível de solidariedade, de cooperação e de compaixão que cultiva face aos coiguais necessitados."72

\section{CONSIDERAÇÕES FINAIS}

A importância e a necessidade de se adotar uma política transacional da sustentabilidade é amplamente reconhecida, embora a sua adesão por alguns países, na assinatura de tratados, ainda seja visto com receio no cumprimento e pagamento das penalidades.

A Transnacionalização do Direito Ambiental é a quebra das barreiras que dificultavam a implantação de um sistema sustentável. Impõe uma perda da soberania absoluta, para uma relativa, onde é preciso respeitar e ceder para as regras internacionais sobre o Direito Ambiental.

A adoção de uma nova ordem mundial aborda problemas novos e antigos, como de origem econômica, tecnológica, social e ambiental. É dever o Estado acompanhar o ritmo da Sociedade e não permitir que esta sucumba em seus erros.

Ao tratar da sustentabilidade, trata-se em nível global, e para propagar o pensamento sustentável, é preciso ir além dos bancos escolar, atingindo todos os níveis educacionais. Buscar-se-á o equilíbrio entre o Desenvolvimento Sustentável, a economia, a cultura, a política e a ecologia, permitindo que todos esses conceitos ultrapassem barreiras.

72 BOFF, Leonardo: Sustentabilidade, o que é - O que não é. 3. ed. Petrópolis - RJ: Vozes, 2014, p.20. 
CARNEIRO, Cheila da Silva dos Passos. RODRIGUES, Patrícia Silva. PASOLD, Cesar Luiz. A transnacionalização da sustentabilidade no direito ambiental. Revista Eletrônica Direito e Política, Programa de Pós-Graduação Stricto Sensu em Ciência Jurídica da UNIVALI, Itajaí, v.11, n.2, 2o quadrimestre de 2016. Disponível em: www.univali.br/direitoepolitica - ISSN 1980-7791.

A instituição de normas de caráter ambiental, a responsabilização pelos atos atentatórios a natureza, princípios como o do poluidor pagador, principio da prevenção e precaução, a adesão de metas, acordos e tratados, tornam-se parâmetros a serem seguidos, que complementaram a Transnacionalidade e garantirão a sustentabilidade do meio ambiente.

Imperativo é a criação de instituições transnacionais ambientais, com atuação global, com força normativa vinculando os Estados nacionais em apenas um agente garantidor e defensor do meio ambiente. Que os Estados participantes tenham consciência de que fazem parte de uma Sociedade civil planetária, que possui seu papel na mudança e perpetuação da espécie humana, e ainda mais, de todo esse planeta que chamamos de casa.

Apresentar as questões ambientais de maneira planetária, com um novo olhar dos Estados para os princípios da solidariedade e fraternidade em busca de um equilíbrio de modo que todos usufruam e desenvolvam-se de modo a não abrir mão de sua própria existência.

Diante de todo o exposto, comprova-se a hipótese básica de que é possível a Transnacionalização da Sustentabilidade no Direito Ambiental, através de políticas de conscientização e a adoção de normas de cunho ambiental, porém, demanda da consciência dos Estados, de que a sua soberania significa muito mais a perpetuação da espécie humana, e que cada um é responsável globalmente pelos recursos naturais, e não somente pelo rio que banha as suas margens.

É cediço que a Política Sustentável ultrapassa barreiras e se sobrepõe à soberania absoluta dos Estados. A Transnacionalização é a ferramenta que garantirá uma maior propagação de seus conceitos e a correta aplicação 
CARNeIRO, Cheila da Silva dos Passos. RODRIGUES, Patrícia Silva. PASOLD, Cesar Luiz. A transnacionalização da sustentabilidade no direito ambiental. Revista Eletrônica Direito e Política, Programa de Pós-Graduação Stricto Sensu em Ciência Jurídica da UNIVALI, Itajaí, v.11, n.2, 2o quadrimestre de 2016. Disponível em: www.univali.br/direitoepolitica - ISSN 1980-7791.

de normas e punição para quem as descumpre. Afinal, as barreiras que levantamos para o desenvolvimento sustentável, não são as mesmas que mantém a poluição em nosso espaço geográfico.

\section{REFERÊNCIAS DAS FONTES CITADAS}

ANTUNES, Paulo de Bessa. Direito Ambiental. 9 ed. Rio de Janeiro: Lumen Juris Editora, 2006.

AQUINO, Sérgio Ricardo Fernandes de; BASTIANI, Ana Cristina Bacega De: As Andarilhagens da Sustentabilidade no Século XXI. 1 ed. Florianópolis: Empório do Direito, 2015.

BECK, Ulrich. 0 que é globalização? Equívocos do globalismo: resposta à globalização. Tradução de André Carone. São Paulo: Terra e Paz, 1999.

BRASIL. Constituição da República Federativa do Brasil (1988). Disponível

em: <http://www.planalto.gov.br/ccivil_03/constituicao/ConstituicaoCompilado .htm.> Acesso em: 10 de abril de 2016.

BRASIL. Senado Federal. Código Civil Brasileiro de 2002. Brasília. Disponível em: <http://www.planalto.g ov.br/ccivil_03/leis/19795.htm>. Acesso em 05 de maio de 2016.

BOFF, Leonardo. Sustentabilidade: o que é - o que não é. 3. ed. Petrópolis - RJ: Vozes, 2014. 
CARNeIRO, Cheila da Silva dos Passos. RODRIGUES, Patrícia Silva. PASOLD, Cesar Luiz. A transnacionalização da sustentabilidade no direito ambiental. Revista Eletrônica Direito e Política, Programa de Pós-Graduação Stricto Sensu em Ciência Jurídica da UNIVALI, Itajaí, v.11, n.2, 2o quadrimestre de 2016. Disponível em: www.univali.br/direitoepolitica - ISSN 1980-7791.

BOSSELMANN, Klaus. O princípio da Sustentabilidade: transformando direito e governança. São Paulo: Revista dos Tribunais, 2015. Tradução Phillip Gil França. Título Original: The Principle of sustainability.

CRUZ, Paulo Márcio. Repensar a Democracia. Revista jurídica FURB. Blumenau, v. 13. 2009.

DERANI, Cristiane. Direito Ambiental Econômico. 3 ed. São Paulo: Saraiva, 2008.

FENSTERSEIFER, Tiago. Direitos fundamentais e proteção do ambiente: a dimensão ecológica da dignidade humana no marco jurídico constitucional do estado socioambiental de direito. Porto Alegre: Livraria do Advogado, 2008.

FIORILLO, Celso Antonio Pacheco. Curso de Direito Ambiental brasileiro. 7 ed. São Paulo:

Saraiva, 2006.

FIORILlO, Celso Antonio Pacheco. Cursos de Direito Ambiental brasileiro. 14. ed. São Paulo: Saraiva, 2013.

FREITAS, Juarez. Sustentabilidade: direito ao futuro. 2. ed. Belo Horizonte: Fórum, 2012.

MACHADO, Paulo Affonso Leme. Direito Ambiental Brasileiro. 9 ed. São Paulo: Malheiros,

2001.

GARCIA, Heloise Siqueira. Avaliação ambiental estratégica e política nacional de resíduos sólidos: uma análise da aplicação em suas ações estratégicas no contexto do Brasil e da Espanha. 1 ed. Florianópolis: Empório do Direito, 2015. 
CARNeIRO, Cheila da Silva dos Passos. RODRIGUES, Patrícia Silva. PASOLD, Cesar Luiz. A transnacionalização da sustentabilidade no direito ambiental. Revista Eletrônica Direito e Política, Programa de Pós-Graduação Stricto Sensu em Ciência Jurídica da UNIVALI, Itajaí, v.11, n.2, 2o quadrimestre de 2016. Disponível em: www.univali.br/direitoepolitica - ISSN 1980-7791.

GIDDENS, Antony. As consequências da modernidade. Tradução de Raul Fiker. São Paulo: Editora UNESP. Título Original: The consequences of modernity, 1991.

GUERRA, Sidney. Resíduos sólidos: comentários à Lei 12.305/2010. Rio de Janeiro: Forense, 2012.

LEMOS, Patrícia Faga Iglesias. Resíduos sólidos e responsabilidade civil pósconsumo. São Paulo: Revista dos Tribunais, 2011.

MILARÉ Edis. Direito do ambiente. 8 ed. São Paulo: RT, 2013.

MIRANDA, Robinson Nicácio de. Direito Ambiental. São Paulo: Rideel, 2009.

PASOLD, Cesar Luiz. Metodologia da Pesquisa Jurídica: Teoria e Prática. 13 ed. rev. Florianópolis: Conceito Editorial, 2015.

PECES-BARBA, Gregorio. Educación para la ciudadanía y derechos humanos. Espasa Calpe, Madrid: 2007.

SCHWENCK, Terezinha. Direitos Humanos Ambientais. Disponível em: http://www.fadipa.br/pdf/schwenck.pdf. Acesso: em 06 maio 2016.

SÉGUIN, Elida. O Direito Ambiental: nossa casa planetária. 2 ed. Rio de Janeiro: Forense, 2002. 
CARNEIRO, Cheila da Silva dos Passos. RODRIGUES, Patrícia Silva. PASOLD, Cesar Luiz. A transnacionalização da sustentabilidade no direito ambiental. Revista Eletrônica Direito e Política, Programa de Pós-Graduação Stricto Sensu em Ciência Jurídica da UNIVALI, Itajaí, v.11, n.2, 2o quadrimestre de 2016. Disponível em: www.univali.br/direitoepolitica - ISSN 1980-7791.

SEIGEL, Micol. Beyond Compare: Comparative Method after the Transnational Turn. Radical History Review, No 91, Winter, 2005.

SILVA, Geraldo Eulálio do Nascimento. Direito Ambiental Internacional. 2. ed. Rio de Janeiro: Thex Ed., 2002.

SILVA, José Afonso da. Direito Ambiental constitucional. 3 ed. São Paulo: Malheiros Editores, 2002.

STELZER. Joana. Direito e transnacionalidade. Curitiba: Juruá, 2011.

STELZER, Joana. Mercado Europeu: direito e análise jurisprudencial. Curitiba: Juruá, 2004.

TRINDADE, Antônio Augusto Cançado. Direitos humanos e meio ambiente: paralelo dos sistemas de proteção internacional. Porto Alegre: Sérgio Antônio Fabris Editor, 1993.

VARELLA, Marcelo Dias. Direito internacional econômico ambiental. Belo Horizonte: Del Rey, 2003.

ZYLBERSZTAJN, David. Sustentabilidade e geração de valor: a transição para o século XXI. Rio de Janeiro: Elsevier, 2010.

Submetido em: Abril de 2016

Aprovado em: Junho de 2016. 